\title{
Views on general knowledge elective courses of ELT departments: Suggested syllabus for diction course
}

\author{
Ahu Akbay a * (10), Kürşat Cesur ${ }^{\text {b }}$ \\ ${ }^{a}$ Çanakkale Onsekiz Mart university,Terzioglu Campus, Çanakkale 17100, Turkey \\ ${ }^{b}$ Çanakkale Onsekiz Mart university,Anafartalar Campus, Çanakkale 17100, Turkey

\section{APA Citation:}

Akbay, A., \& Cesur, K. (2019). Views on general knowledge elective courses of ELT departments: Suggested syllabus for diction course. Journal of Language and Linguistic Studies, 15(4), 1332-1354.

Submission Date: 09/09/2019

Acceptance Date: 15/11/2019

\begin{abstract}
Turkish Council of Higher Education (CoHE) has updated the curriculums of teaching programmes recently by increasing the percentage of the elective courses. This change became the focus of this study. The study aims to find out the four most preferred General Knowledge (GK) elective courses among English language teachers and the criteria that determine their preferences and to design a syllabus for the most preferred course. It incorporated two phases and in the first phase, mixed method sequential exploratory research design was carried out. Having reviewed the curriculums of ELT departments of all 45 state universities, the researchers made a document analysis on the GK electives and developed a questionnaire which was conducted to 1093 participants online. The data were analyzed by Microsoft Excel and SPSS 21.0. Mixed method sequential transformative research design was used in the second phase. Having done a document analysis, a questionnaire was developed, and administered to 114 English language teacher educators online. The data were analyzed by Microsoft Excel and SPSS 21.0. The findings of the first phase indicated that the four most preferred GK elective courses were 'Diction', 'Presentation Skills', 'Human Relations and Communication' and 'Language and Culture', and 'personal needs and interests' was the most important criterion. From the results of the second phase of the study, 18 topics were specified to suggest a topic-based syllabus for 'Diction'. Based on the findings of the study, some implications for ELTPs and for further research were presented at the end of the study.
\end{abstract}

(c) 2019 JLLS and the Authors - Published by JLLS.

Keywords: Pre-service EFL teachers; in-service EFL teachers; general knowledge elective courses; suggested syllabus; diction

\section{Introduction}

Many changes and innovations along with the process of adaptation to the European Union (EU) and in association with the Bologna process have been introduced in the area of language education. English language teaching programs (ELTP) were updated in 1997, 2006 and recently in 2018 under the coordination of the CoHE. Besides the document 'General Competencies for Teaching Profession (2017-2023)' developed by the Ministry of National Education (MoNE) in 2017, scientific research

\footnotetext{
${ }^{*}$ Corresponding author. Tel.: +0-000-000-0000

E-mail address: ahuyapar@comu.edu.tr
} 
studies on the application of the programmes, procedural evaluations and educational reports have been taken into advisement.

In 2016, some regulations related to professional teaching knowledge (PTK) and enhancing the percentage of GK courses were required due to defective points in the system. In addition to this, universities were granted authorization in terms of determining nearly $25 \%$ of the courses apart from the obligatory courses in the programmes. As a consequence of these regulations, teaching programmes at universities consisted of 50-60\% of subject area knowledge (SAK), 25-30\% of PTK, and 15-20\% of GK courses.

In 2018, the CoHE examined the existing teacher education programmes in terms of their learning outcomes, weekly course hours, their national and European Credit Transfer and Accumulation System (ECTS) and declared another regulation. According to the recent regulation announced by CoHE: (1) A common core curriculum has become possible for all ELTPs, (2) ELTPs are formed of three major areas that are PTK by $34 \%$, SAK by $48 \%$, GK by $18 \%$, (3) the percentage of elective courses has been increased up to $25 \%$ within the scope of Bologna process, (4) the CoHE formed an elective course pool and categorized all similar lessons under one specific title in order to avoid ambiguity for the elective courses, (5) eighteen courses were identified as 'GK Electives' equivalent of 12 ECTS throughout the four-year programme (CoHE, 2018).

This recent change necessitated new elective courses to be opened in teaching programs. The needs of pre-service teachers and the experiences of in-service teachers are really important to be considered before offering new GK elective courses. Therefore, this research study aimed to find out the most preferred elective courses among pre-service and in-service EFL teachers and the criteria that determine their preferences and to design a syllabus for the most preferred GK elective course.

\subsection{Literature review / Theoretical background}

Language policy in Turkey has gone through many innovations and reforms after the transfer of teacher training function to universities in 1982. Turkey is passing through a period of reform and conversion in ELT systems in order to meet its objective of keeping up with the European system of language education and "adapting its existing system to new educational norms", especially in the ELT curriculum (Kırkgöz, 2007, p. 227). Besides the European system, remarkable technological improvements also required qualified language teachers and up-to-date curriculums. In order to meet these requirements, reforms on teacher education programs were implemented in 1997 and 2006. Throughout each updating process, commissions were formed and a field scanning was performed besides the scientific researches on the application of the programmes, the evaluations of the procedures and educational reports.

\subsubsection{The 2018 ELT curriculum reform}

In 2016, CoHE started to plant the seeds of a new reform in education due to the defective points of the existing program. Within the scope of this, the current teaching programs were reviewed and evaluated in terms of their purposes, learning outcomes, weekly course hours, national and ECTS credits. As a result of the evaluation, deficiencies of the current system were identified and in 2018, $\mathrm{CoHE}$ declared another reform in teacher education programs. According to these regulations (CoHE, 2018) regarding the implementation of the recent reform, the programs will come into effect in 20182019 academic year with the first-year students. Students who are already enrolled in a program will continue with the former program. The semesters, national and ECTS credits of compulsory and elective courses in the new program will not be changed on any account. Also, GK courses are to be planned and run by coordinatorships (coordination units), which will be formed by faculty administrations. In terms of curriculum, the most outstanding regulation was that a common core curriculum was enabled 
for all ELTPs. The new curriculum (see Appendix A) consisted of three major areas, which are PTK by $34 \%$, SAK by $48 \%$, GK courses by $18 \%$. The total number of class hours of the courses decreased to 155 , whereas the percentage of elective courses increased up to $25 \%$ in the framework of Bologna process.

In terms of elective courses, the most significant change in the program was that an elective course pool was formed and all similar courses were classified under one specific title in order to avoid ambiguity. In the elective course pool, 22 courses were identified as 'PTK electives', 13 courses were identified as 'SAK electives', and 18 courses were identified as 'GK electives'. In this new system, universities are required to open minimum 6 different elective courses for each area in every semester as students are supposed to pick 6 courses from 'PTK electives' and 'SAK electives', and 4 courses from 'GK electives' throughout their degree programmes. Within the scope of this regulation, universities were also granted authorization in terms of opening up to 6 more courses for 'PTK' and 'SAK' areas, in addition to the elective courses pool suggested by CoHE on condition that they apply to CoHE within the stated time. Since universities need consent from CoHE, they are expected to give reasons and course descriptions in accordance with the needs, interests and demands of students. Moreover, SAK electives are required to be directly associated with teaching the subject area. On the other hand, there are not any constraints related to GK electives and no consent is needed while opening courses in the mentioned area.

\subsubsection{Studies on suggested syllabi in the ELT departments}

Many studies have been conducted to suggest a syllabus for teachers, policy makers and curriculum designers. Most of these studies aim to fill a gap, remedy the deficiencies or bring a new perspective to the current system. In these circumstances, both students and teachers' needs, interests and wishes have an impact on the design of the syllabi for the courses as they are the part of the system.

In a study carried out by Yanç (2002), an 'Advanced Reading' course syllabus for the first year first semester students in ELT departments was developed. A needs analysis was carried out by the researcher to determine the needs and interests of both students and teachers. 409 students and 39 instructors participated in the study. A teachers' and a students' questionnaire were used to collect data and a syllabus consisting of 10 units was prepared in accordance with the needs and interests of the students and teachers. Saraç (2003) conducted another study and suggested a syllabus for the teaching of 'Poetry' course in ELT departments. As 'Poetry: Analysis and Teaching' was added to the curriculum of ELT departments as a compulsory course, the need of a syllabus suggestion arose. Therefore, the researcher prepared a syllabus based upon an evaluation of the needs and interests shared and differentiated among a target group of students taking the course. In the light of the data collected through a questionnaire, the last version of the syllabus was developed. Later, Gündüz (2005) carried out a study and suggested a syllabus for the 'Introduction to British Literature I' course after investigating not only the present condition and syllabi in use but also the opinions, ideas and needs of students in ELT departments of education faculties. 266 students and 6 lecturers contributed to the data collection through questionnaires and interviews. As a result of the study, an alternative definition to CoHE's definition for the course was offered and a syllabus with definite aims and objectives allied to an eight-unit course book with course materials covering the course goals and objectives was suggested by the researcher. Another study belongs to Ekşi (2008), who developed a syllabus at B2 level in accordance with the standards defined in CEF for the preparatory classes of Gazi University ELT Department. A study skills questionnaire, B2 'Can Do' statements, and an interest checklist were administered to obtain a profile of ELT preparatory students. Having analyzed the data gathered, and discussed the shortcomings of the current programme for ELT classes; the researcher suggested a syllabus for ELT preparatory year. Moreover, in a study conducted by Altay (2008), a syllabus for the 'Advanced Writing Skills' course at ELT departments was developed. A questionnaire was given to lecturers from ELT departments of Hacettepe University and 
Gazi University and a students' questionnaire was administered to second grade ELT students of Hacettepe University. In accordance with the data collected, the researcher suggested a syllabus. Finally, Akman Yeşilel (2012) carried out a study and suggested a syllabus for the 'Effective Communication Skills' course for the pre-service English language teachers at Gazi University. The data gathered via a variety of scales throughout the study. On the one hand, a 'Teacher Communication Behaviour Student Questionnaire' was administered to high school students to explain their views on their English language teachers' communication skills and on the other side their teachers were asked to evaluate their own communication skills by the help of 'Do You Communicate Positively?' and 'Communication Skills Inventory'. The pre-service language teachers and the instructors who deliver 'Effective Communication Skills' courses were given a checklist on communication skills topics to decide on modules of the syllabus. In the lights of the data collected, a syllabus was developed and implemented on the first-grade pre-service English teachers at Gazi University. The process was tested by the researcher and the results showed that the suggested syllabus contributed to communication skills of the pre-service language teachers.

\subsection{Research questions}

Bearing the studies on suggested syllabi in mind, a suggested syllabus for the most preferred GK elective was aimed to be developed with the help of the following research questions:

RQ1 What is the most important criterion that determines the participants' preferences of the GK elective courses?

RQ2 What are the 4 most preferred GK elective courses?

RQ3 Which topics should constitute the syllabus of the most preferred GK elective?

\section{Method}

The current study incorporated two phases which utilized two separate mixed methods research designs to gather both qualitative and quantitative data. Creswell (2014, p. 177) calls it the "multiphase mixed methods" as several mixed methods projects are conducted throughout the study "for a single overall purpose". This type of research was adopted by the researchers as the study required two phases to determine the most preferred GK elective course among pre-service and in-service EFL teachers initially and design a syllabus for the most preferred course.

\subsection{First Phase of the Study}

The first phase of the study used mixed methods sequential exploratory research design and it can be summarized in a figure.

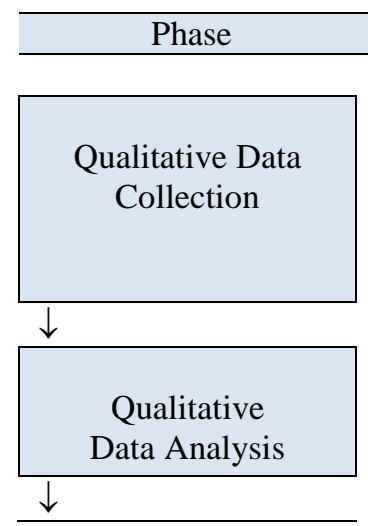
Procedure Products

- Document Analysis: Online ELT Curriculums of State Universities (N:45)

- $\quad$ Reviewing CoHE's Suggested ELT Curriculum

- Combining similar courses under one title,

- $\quad$ Sorted and filtered in Excel
- $\quad$ Elective Courses opened in State Universities

- 18 GK Electives suggested by $\mathrm{CoHE}$

- The most frequent Elective Courses

- $\quad$ Frequency Tables 


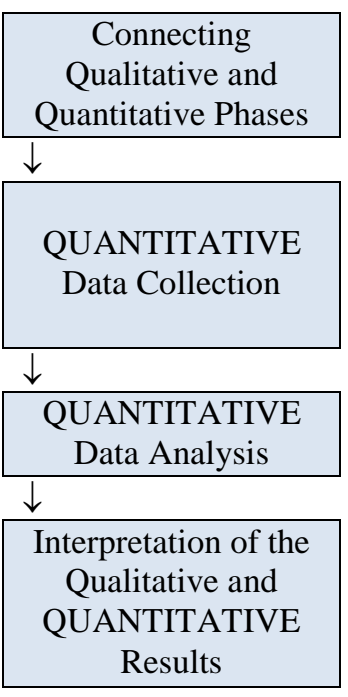

- Analysing the frequency tables, 28 GK Electives were derived from the qual phase

- $\quad$ Piloting to teacher educators \& in-service teachers (N:14)

- Google forms web-based survey (N:1093)

- Frequencies

- Interpretation and explanation of qual \& QUAN results
- A Questionnaire consisting of 36 items with 3 parts

- Nominal (Categorical) item scores

- Descriptive statistics

- Discussions

- Implications for the ELTPs and further research

Figure 1. Visual model for mixed methods sequential exploratory design procedures (adapted from Ivankova, Creswell \& Stick, 2006)

\subsubsection{Participants}

1093 pre-service and in-service EFL teachers got involved in the first phase of the study all around Turkey voluntarily by means of snowball sampling. In terms of gender, $833(76.2 \%)$ of the participants were female and $260(23.8 \%)$ participants were male. In terms of service status, $436(39.9 \%)$ of the participants were pre-service teachers and $657(60.1 \%)$ participants were in-service teachers. A pilot study was carried out with 10 in-service teachers and 4 teacher educators from ELT departments.

\subsubsection{Instrument}

In order to gather information for the quantitative part of the study, a questionnaire was developed by the researchers consisting of 36 items with 3 parts. The first part which consisted of personal information aimed to find out the gender and service status of the participants. Having 5 items, the second part sought to elicit the major criterion that determines the preferences of the participants while preferring GK elective courses. Based on the fact that students are required to pick 4 courses from 'GK electives' throughout their degree programmes stated by CoHE, in the final part of the questionnaire the participants were asked to choose 4 elective courses out of 28 . The 'other' option was added to the questionnaire considering the possibility that the participants might have different opinions or interests. The questionnaire (See Appendix B) was formed as a web-based survey with Google Forms and intended to reveal which 4 GK electives were preferred by the participants in order to determine the most preferred GK elective.

\subsubsection{Data collection procedures}

Due to the mixed methods sequential exploratory research design, both qualitative and quantitative data were collected throughout the first phase of the study. As a part of the qualitative data collection, a document analysis which is "a standardized process for revising or analyzing document or reportsboth paper-based and online materials" was conducted (Köksal \& Ulum, 2018, p. 164). GK elective courses stated in the online curriculums of the ELT departments of 45 state universities in Turkey were reviewed. 700 elective courses were found and listed in 37 of the universities reviewed. There were not any GK elective courses or GK electives were not stated in the online curriculums of the 8 state universities reviewed.

In terms of quantitative data collection, a questionnaire was developed after analyzing the data obtained in the qualitative part of the study. A pilot study was conducted to 10 in-service teachers and 
4 teacher educators from ELT departments online in order to identify any possible problems or deficiencies with content, wording or lay out. As a result of the pilot study, there were not any deficiencies, so the questionnaire was administered to 1093 pre-service and in-service EFL teachers online by snowball sampling for about one month. For the validity and reliability issues, triangulation was used. As Bryman (2004, p. 1142) defined "triangulation refers to the use of more than one approach to the investigation of a research question in order to enhance confidence in the ensuing findings". Besides triangulation, before the pilot study, the researchers consulted two experts to make sure if any changes or revisions were needed.

In order to find the most preferred GK elective course, the data was collected through document analysis from the online curriculums of the ELT departments of state universities first. Having reviewed the 'English language teaching program' published by CoHE and removed some courses which were changed as compulsory, the GK Elective Course Questionnaire was developed by the researchers. Having conducted a pilot study, the instrument was administered to pre-service and in-service teachers who participated in the first phase of the study.

\subsubsection{Data analysis}

As the mixed methods sequential exploratory research design was used in the first phase of the study, both qualitative and quantitative data were collected and they both required separate and sequential analyses.

Having done a document analysis, 700 elective courses were derived from the online curriculums of the ELT departments of state universities. In terms of qualitative data analysis, the researchers used Microsoft Excel as Meyer and Avery (2009, p. 110) clearly stated that "Excel's 'crunching' ability is not limited to numerical calculations. Rather its logical functions can provide significant aid in qualitative analysis". Firstly, 700 courses were transcribed into Microsoft Excel and a list of courses was formed. Then the researchers sorted and filtered the courses with the same title. After analyzing the 'English language teaching program' published by CoHE, 'Community Service Practices', 'Foreign Language' and 'Information Technology' courses were removed from the list as they became 'compulsory' with regard to the 2018 ELT curriculum reform. 461 different elective courses were determined out of 700 courses. Similar courses were filtered and combined under one title and Microsoft Excel was used to analyze the prevalence of these courses. A 'GK elective course pool' with 28 electives with a frequency of 3 and more was formed including 18 GK electives suggested by CoHE in 2018. The questionnaire for the quantitative part of the study was developed by the researchers with these 28 electives from 'GK elective course pool'. As a part of the quantitative data analysis, the data collected through the questionnaire was typed into SPSS 21.0. Frequency distributions were provided as part of the descriptive statistics.

\subsection{Second Phase of the Study}

The second phase of the study used mixed methods sequential transformative research design and it can be summarized in a figure. 


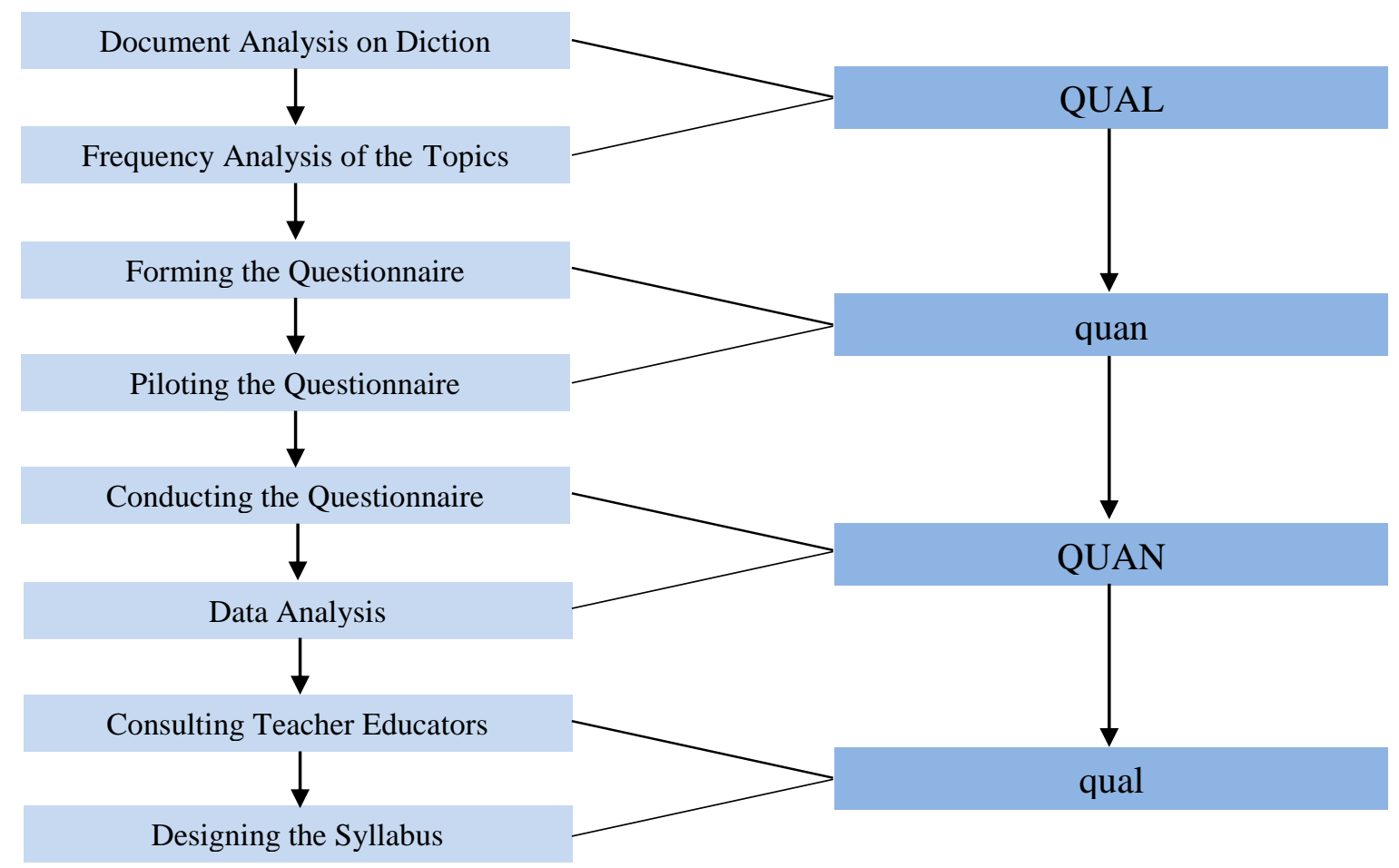

Figure 2. Visual model for mixed methods sequential transformative design procedures

\subsubsection{Participants}

114 English language teacher educators working at Turkish universities participated voluntarily in the second phase of the study. Before the pilot study, the questionnaire was reviewed and revised by a Turkish language teacher educator who teaches Diction. The pilot study was also carried out online with 28 English language teacher educators in ELT departments. In the qualitative part of the second phase of the study, the researchers consulted four teacher educators working in the Faculty of Education at Çanakkale Onsekiz Mart University. The three of the teacher educators are in the ELT department and chosen particularly as one of them taught 'Presentation Skills', whereas the other teaches 'Listening and Pronunciation'. One of the teacher educators is in the Turkish Language Teacher Education department and chosen particularly as she gives courses on 'Speech' and 'Diction' and has written a book on 'Diction'.

\subsubsection{Instruments}

As the most preferred GK elective course by the participants in the first phase of the study was Diction, the second phase intended to design a suggested syllabus for the course. In order to gather the topics for the course, a document analysis was done and the data obtained from the document analysis was used to form a questionnaire. The Diction questionnaire was developed by the researchers consisting of 28 topics in a 5 point Likert Scale rating from 'not important' to 'very important'. There was also the 'other' option as the last item in the questionnaire. The Diction questionnaire (see Appendix C) was formed as a web-based survey with Google Forms and intended to determine the importance of the topics in terms of the course in ELT departments. In order to verify the reliability of the Diction questionnaire administered to English language teacher educators, SPSS was used.

Table 1. Cronbach's alpha values of diction questionnaire

\begin{tabular}{lllll}
\hline \multirow{2}{*}{ Instrument } & $\begin{array}{l}\text { Alpha } \\
\text { Reliability }\end{array}$ & $\mathrm{n}$ & & \\
\cline { 3 - 5 } & Valid & Excluded & Total \\
\hline Diction questionnaire & .956 & 114 & 0 & 114 \\
\hline
\end{tabular}


The result indicated that Cronbach's alpha value is .956, which means that Diction questionnaire is reliable according to Büyüköztürk (2006) who recommends levels of .70 or higher for scales like these.

\subsubsection{Data collection procedures}

As the second phase of the study used mixed methods sequential transformative research design, both qualitative and quantitative data were collected in the second phase. In terms of qualitative data collection, a document analysis was done by reviewing the syllabi of state, private and foundation universities on Diction as it was the most preferred GK elective course by the participants in the first phase of the study. 291 topics were found in 25 departments of 22 universities. The researchers also reviewed the books on Diction to collect data for the questionnaire which aimed to determine topics for the suggested syllabus in the study. 204 topics were obtained from 17 books on Diction. 495 topics were gathered and listed from the universities and books in total.

After the qualitative data analysis, a questionnaire as a part of the quantitative data collection was developed. The participants were intended to rate the importance of the topics for the course. There was the 'other' option in the questionnaire considering the possibility that the participants might want to add different topics which were not offered in the questionnaire. The pilot study was carried out online with 28 teacher educators in ELT departments to detect any potential problems with content, wording or lay out. Some participants of the pilot study indicated that the topics in the questionnaire would better be both in Turkish and English in order to eliminate the misunderstandings. They stated that some terms were unfamiliar to them as they were Turkish terms related to the field. Therefore, the researchers added the English equivalents of the Turkish terms to the questionnaire and formed a web-based survey with Google Forms. The link for the final form of the questionnaire was sent to the participants by email so that the participants would participate in the study if they wanted and they would be anonymous due to the web-based survey. It took over two months to conduct the questionnaire and gather data for the study.

In order to maintain validity, triangulation was used for data collection. The purpose in research is using "two or more aspects of research to consolidate the design to increase the ability to read the findings" (Campbell \& Fiske, 1959; Denzin, 1970; Polit \& Hungler, 1995, as cited in Thurmond, 2001, p. 253). In addition to triangulation, before the application of the pilot study, the researchers consulted to an expert and made the necessary revisions and changes on the questionnaire.

\subsubsection{Data Analysis}

The mixed methods sequential transformative research design, which is based on collecting both qualitative and quantitative data sequentially, requires both types of analyzes; qualitative data analysis and quantitative data analysis. The qualitative data gathered from the universities and books were typed into Microsoft Excel and 495 topics were obtained in total. Same topics were combined under one title and filtered resulting in 138 different topics. The prevalence of these 138 topics was analyzed by Microsoft Excel (Meyer \& Avery, 2009) and 28 topics were derived from the list with a frequency of 3 and more. The quantitative data collected through the questionnaire conducted to English language teacher educators were transferred into SPSS 21.0 and quantitative analysis was done through SPSS. Descriptive statistics were applied in terms of the research questions and the mean values and the standard deviation of the items were calculated. The scale was divided into five categories ranging from '1.00-1.79 = not important, 1.80-2.59 = slightly important, 2.60-3.39 = moderately important, 3.40-4.19 = important and 4.20-5.00 = very important' (Hemmati \& Mojarrad, 2016) and the results were analyzed accordingly. 


\section{Results}

\subsection{Results of research question 1}

So as to find out the most important criterion that determines the pre-service and in-service EFL teachers' preferences of the GK elective courses, the participants were asked to pick the major criterion in the second part of the questionnaire and descriptive statistics were calculated. Table 2 displays the frequency distributions of the participants' opinions.

Table 2. The criteria stated by the participants in their preferences of GK electives $(\mathrm{N}=1093)$

\begin{tabular}{lll}
\hline Criteria & $\mathrm{f}$ & $\%$ \\
\hline Personal Needs and Interests & $\mathbf{6 2 8}$ & $\mathbf{5 7 . 5}$ \\
Contribution to Professional Development & 343 & 31.4 \\
Lecturer & 88 & 8.1 \\
Course Title & 32 & 2.9 \\
Other & 2 & 0.2 \\
Total & 1093 & 100 \\
\hline
\end{tabular}

As shown in Table 2 above, the most important criterion that determines pre-service and in-service EFL teachers' preferences of the GK elective courses is their 'personal needs and interests' with a frequency of 628 (57.5\%) among 1093 participants. The 'contribution to professional development' is the second most important criterion that determines the participants' preferences with a number of 343 participants and constituted $31.4 \%$ of the total. Two participants stated that there are 'other' criteria while preferring GK electives. One of them specified that they would choose courses 'which do not require hard work and are easy to pass', whereas the other indicated that 'they cannot choose a course, they are enrolled in courses available instead'.

\subsection{Results of research question 2}

In order to determine the four most preferred GK elective courses among pre-service and in-service EFL teachers, the participants were asked to choose 4 courses out of 28 GK electives from the GK Elective Course Questionnaire. The frequency distributions of all 28 courses are stated in Table 3.

Table 3. Frequency distribution of the four most preferred GK electives $(\mathrm{N}=1093)$

\begin{tabular}{lll}
\hline Elective Courses & f & $\%$ \\
\hline Diction & $\mathbf{5 5 3}$ & $\mathbf{5 0 , 6}$ \\
Presentation Skills & $\mathbf{5 0 7}$ & $\mathbf{4 6 , 4}$ \\
Human Relations and Communication & $\mathbf{4 2 3}$ & $\mathbf{3 8 , 7}$ \\
Language and Culture & $\mathbf{3 5 4}$ & $\mathbf{3 2 , 4}$ \\
Professional English & 302 & 27,6 \\
Mythology & 210 & 19,2 \\
Turkish Sign Language & 208 & 19,0 \\
First Aid & 187 & 17,1 \\
Nutrition and Health & 155 & 14,2 \\
Career Planning and Development & 141 & 12,9 \\
History and Philosophy of Science & 134 & 12,3 \\
\hline
\end{tabular}




\begin{tabular}{lll}
\hline Art and Aesthetics & 129 & 11,8 \\
Democracy and Human Rights & 115 & 10,5 \\
Science and Research Ethics & 113 & 10,3 \\
Media and Communication & 110 & 10,1 \\
Cinema History & 102 & 9,3 \\
Media Literacy & 99 & 9,1 \\
Sports & 86 & 7,9 \\
Contemporary Turkish Literature & 86 & 7,9 \\
Understanding and Overcoming Addiction & 71 & 6,5 \\
Economics and Entrepreneurship & 56 & 5,1 \\
Turkish Folk Dances & 42 & 3,8 \\
Turkish Cultural Geography & 42 & 3,8 \\
Music History & 42 & 3,8 \\
Traditional Turkish Handicrafts & 34 & 3,1 \\
Turkish Art History & 26 & 2,4 \\
Traditional Turkish Music & 19 & 1,7 \\
Traffic & 18 & 1,6 \\
\hline
\end{tabular}

As shown in Table 3 above, the most preferred GK elective course is 'Diction' with a frequency of 553 (50.6\%) among 1093 participants. 'Presentation Skills' is the second most preferred GK elective course with a number of 507 participants and constituted $46.4 \%$ of the total. 'Human Relations and Communication' is the third most preferred elective with a number of 423 participants and constituted $38.7 \%$ of the total. The fourth most preferred elective is 'Language and Culture' with a frequency of 354 (32.4\%). In addition to the courses stated in the questionnaire, participants also added some courses for the 'other' option. 'Digital Learning', 'Fairy Tales in World Literature', 'History of Technology' and 'Ottoman Architecture' were the courses indicated by the participants.

\subsection{Results of research question 3}

English language teacher educators' opinions on the content of the suggested syllabus for the most preferred elective course were asked by using 5-point Likert scale. There were 28 topics and teacher educators were asked to rate these topics considering their importance in terms of the Diction course.

Table 4. Topics for the Most Preferred Elective Course 'Diction' $(\mathrm{N}=114)$

\begin{tabular}{lll}
\hline Topics & Mean & SD \\
\hline Communication Skills & 4,6930 &, 75407 \\
Language & 4,6316 &, 68179 \\
Presentation Skills & 4,5789 &, 75134 \\
Body Language & 4,5263 &, 77814 \\
Practice & 4,5175 &, 71930 \\
Public Speaking Practice & 4,5088 &, 74365 \\
Oral Narratives & 4,4825 &, 80080 \\
Extemporaneous and Impromptu Speeches & 4,4649 &, 77779 \\
Vocabulary & 4,4386 &, 80962 \\
Fluency & 4,4123 &, 83942 \\
Gestures and Mimics & 4,3947 &, 84789 \\
Pronunciation & 4,3860 &, 90728 \\
Oratory & 4,3772 &, 89631
\end{tabular}




\begin{tabular}{lll} 
Stress and Intonation & 4,3333 &, 81650 \\
Basics of Diction & 4,3246 &, 87740 \\
Phonetics & 4,2368 &, 92462 \\
Articulation & 4,2018 &, 85373 \\
\hline Punctuation & 4,1579 &, 95546 \\
Pause & 4,1404 &, 90110 \\
Rate of Speech & 4,0877 &, 97365 \\
Improvisation & 4,0526 &, 77393 \\
Linking & 3,9298 &, 93808 \\
Breathing Training & 3,9211 & 1,03175 \\
Speech Terminology and Types of Speech & 3,8860 & 1,01108 \\
Vowels and Consonants & 3,8509 &, 96149 \\
Diaphragmatic Breathing Exercises & 3,7719 & 1,01349 \\
Speech Disorders & 3,7632 &, 99825 \\
Textual Analysis (Practice) & 3,7456 & 1,01154 \\
\hline
\end{tabular}

Descriptive statistics were applied and mean values of each item were calculated as shown in Table 4. As the scale was divided into five categories and the mean value over 4.20 indicated 'very important', 17 topics were determined as 'very important' out of 28 topics. In addition to the topics stated in the questionnaire, participants also added some topics for the 'other' option. Communication strategies, use of humor, formulaic chunks and cultural awareness considering body language, gestures and mimics as they have different meanings in different cultures, were the topics stated as 'other' in the questionnaire by the participants.

\section{Discussion}

The results of the study revealed that the most important criterion that determines pre-service and inservice EFL teachers' preferences of the GK elective courses is their 'personal needs and interests' with a frequency of $628(57.5 \%)$ among 1093 participants. The study has the same findings with Daly and Last (2017), Hennessy, Hernandez, Kieran, and McLoughlin (2010), Palmer, Burke, and Aubusson (2017), Purcell, Dunnion, and Loughran (2010), Sabir, Ahmad, Ashraf, and Ahmad (2013), Samara (2015), Stiles-Clarke and MacLeod (2016), Tezcan and Gümüş (2008) and Ulusoy et al. (2012)'s studies in which participants stated their needs or interests as one of the important determinants in choosing a course. As students enroll in many courses throughout their education and these courses are mostly compulsory, they can make the most of the opportunity and choose as they wish when they are given a chance. The best part of this is asserted by Howorth $(2001$, p. 28) who suggested that "students who choose out of interest will learn more, enjoy more and spend more hours studying and as a bonus they may also get higher grades because they will have a better understanding of the subject".

Four most preferred GK elective courses among pre-service and in-service EFL teachers were explored and the findings revealed that 'Diction' is the most preferred GK elective course among the participants in consideration of their personal needs and interests. This result is directly in line with the findings of studies conducted by Karakelle (2005), Kuram and Çiftçi (2018) and Sadiku (2015) which addressed the importance and necessity of diction in teaching profession. In addition to all these, some studies carried out by Akkaya (2012), Arslan (2012), Baki and Kahveci (2017) and Güvey Aktay (2019) suggested 'Diction' as a course in teaching curriculums. As diction is the way of saying or expressing words clearly and it is mostly related to language and speaking, teachers but especially language teachers are in need of diction. Sanderson (1983) portrays a good language teacher as someone who has clear and good pronunciation, stress and intonation. Moreover, Hoque (2009) highlights that a good language 
teacher should be a very good speaker with good communication skills. Gürzap (2011) declares that a teacher with poor and incorrect speaking cannot convey knowledge to his students no matter what or how much he knows. His words enunciate the significance of diction for teachers.

In addition to 'Diction', findings of the study revealed that participants preferred 'Presentation Skills'. The importance of presentation skills in the language classroom was stated in Brooks and Wilson (2015), Çalışoğlu (2019), Temizkan (2017) and Živković's (2014) studies. Another course preferred by pre-service and in-service teachers in terms of GK electives was 'Human Relations and Communication'. Studies conducted by Baykara Pehlivan (2005), Doğan (2009), Şahin Baltacı (2018) and Taşdemir, Taşdemir, Buyuran, and Cesur (2016) indicated that human relations and communication has an important role in teaching. Besides, Dilekmen, Başçı, and Bektaş (2008) and Öztürk Yılmaztekin (2015) suggested courses on communication in teaching curriculums. 'Language and Culture' as being the fourth course preferred by the participants is a prominent issue and studies carried out by Choudhury (2014), Göçer (2013), Gürler (2018), Kizılaslan (2010), Tran and Pham (2017) and Yaman (2017) laid stress on language and culture and confirmed the importance of culture in terms of language teaching.

As speaking is the most frequently used communication tool not only for people but also for teachers in classroom, 'Diction' is not an unexpected finding in the study. Besides, the other three courses preferred by the participants are directly related to speaking and communication and also interrelated with diction. Many studies carried out by Baki and Kahveci (2017), Başaran and Erdem (2009), İşcan and Karagöz (2016) and Katrancı and Kuşdemir (2015) revealed pre-service teachers' concern about speaking especially in public. In definitions of an effective or ideal teacher made by students and researchers, speaking and communication skills were emphasized in most studies (e.g. Başaran \& Baysal, 2016; Durukan \& Maden, 2010; Kahramanoğlu \& Bay, 2016; Özkan \& Arslantaş, 2013; Taşkaya, 2012; Yanpar Yelken, Çelikkaleli, \& Çapri, 2007).

In terms of the topics that should constitute the syllabus of the most preferred GK elective course 'Diction', communication skills, language, presentation skills, body language, practice, public speaking practice, oral narratives, extemporaneous and impromptu speeches, vocabulary, fluency, gestures and mimics, pronunciation, oratory, stress and intonation, basics of diction, phonetics and articulation were evaluated as 'very important' topics by the participants. 'Communication skills' is the highest ranked topic with a mean value of 4.69 (SD = .754). Similarly, studies carried out by Akpinar (2009), Majid, Jelas, Azman, and Rahman (2010), Milli and Yağc1 (2016), Selanik Ay (2015) and Üstünsel (2011) also focused on the importance of communication skills in teaching. Another topic directly related to communication skills is 'body language' with a mean value of 4.52 ( $\mathrm{SD}=.778)$. Baş (2010), Başaran and Erdem (2009), Katrancı and Kuşdemir (2015) and Yang (2017) studied and highlighted the necessity of body language in teaching and Üstünsel (2011) also suggested a course on communication skills and body language in the curriculums of education faculties in the light of the study she conducted. 'Gestures and mimics' is another important topic in the findings of the study which was also stated in Aktaş and Gündüz (2009), Çalışkan and Yeşil (2005), Eyüp (2013), Güvey Aktay (2019), and Yang (2017)'s studies in teaching context. 'Pronunciation' is another prominent topic that was found out and Akkaya (2012), Başaran and Erdem (2009) and Doğan (2009)'s studies referred to the significance of pronunciation. In addition to pronunciation, Akkaya (2012), Başaran and Erdem (2009) and Selanik Ay (2015) highlighted the impact of stress and intonation in terms of effective speech.

In addition to the topics derived from the questionnaire, 'voice and breathing' was added to the suggested syllabus after consulting teacher educators (see Appendix D). The studies conducted by Aktaş and Gündüz (2009); Bağc1 (2008); Eyüp (2013); İşcan, Karagöz, and Almalı (2017) and Üstünsel (2011) support teacher educators' opinions on teaching voice and Güvey Aktay (2019) and Katranc1 and Kuşdemir (2015)'s studies sustain teacher educators' opinions on teaching breathing. In addition to all 
these studies, Akkaya (2012), Baki and Kahveci (2017) and Kuram and Çiftçi (2018) indicated the importance of voice and breathing in diction education.

\section{Conclusion and Suggestions}

The study was carried out in two different phases and utilized two mixed methods research designs first to find out the most preferred GK elective course and then to design a syllabus for that most preferred course. In the first phase of the study, mixed method sequential exploratory research design was wielded. Qualitative data was gathered by means of document analysis on the GK electives of 45 state universities and a questionnaire which was later conducted to 1093 participants online was developed with the help of the data. In the second phase of the study, the researchers followed mixed method sequential transformative research design. After the document analysis of the topics regarding diction, a questionnaire which was applied to 114 English language teacher educators was formed. The results of the first phase demonstrated that 'Diction', 'Presentation Skills', 'Human Relations and Communication' and 'Language and Culture' were among the four most preferred GK elective courses. The participants prefer these courses particularly because of their 'personal needs and interests'. According to the results of the second phase of the study, 18 topics were listed to suggest a topic-based syllabus for the course 'Diction'.

Bearing the results of the study in mind, the students' either personal or professional needs and interests should be taken into consideration while both offering an elective course and designing the syllabus of any elective courses. To gain new perspectives on the needs and interests of teacher candidates, researchers and academicians can utilize the 'GK Elective Course Questionnaire' provided at the end of the study (See Appendix B). More elective courses should be offered in the ELTPs so that pre-service teachers may have a wide range of course choice. ELTPs may meet the needs and interests of their students by offering more elective courses from different subject areas. As the courses the participants preferred were mostly related to speaking skills, more courses on speaking and communication skills should be offered in order to meet the pre-service teachers' needs. As 'Diction' appeared in the curriculums of only 3 state universities, but being the most preferred GK elective course, it should be offered by the ELT departments of more universities. Not only the most preferred four GK electives, but also some other electives such as 'Turkish Sign Language' and 'First Aid' can also be considered as new elective courses for the future teachers of English. Finally, teacher educators can make use of the topics provided in the suggested syllabus in this study if they plan to give the course 'Diction'. They can add topics to or omit topics from their syllabus by using the list provided in this study.

As the current study investigated only GK area, further research studies are suggested to shed light on the other two major areas PTK and SAK. Further research can also be carried out with more participants in order to gain comprehensive data on the issue. Furthermore, interdisciplinary studies are suggested as GK elective course pool constitutes courses from different disciplines. Finally, the current study may arouse the interests of the researchers on course choice either elective or compulsory as the issue is a new one to be explored and clarified.

\section{References}

Akkaya, A. (2012). Öğretmen adaylarının konuşma sorunlarına ilişkin görüşleri. Mustafa Kemal Üniversitesi Sosyal Bilimler Enstitüsü Dergisi, 9(20), 405-420. 
Akman Yeşilel, D. B. (2012). A suggested syllabus for the "Effective Communication Skills" course for the pre-service English language teachers at Gazi University (Unpublished doctoral dissertation). Gazi University, Institute of Educational Sciences, Ankara, Turkey.

Akpınar, K. D. (2009). Developing communication skills of EFL teacher trainees. Journal of Language and Linguistic Studies, 5(1), 110-126.

Aktaş, Ş. \& Gündüz, O. (2009). Yazılı ve sözlü anlatım. Ankara: Akçağ Yayınları.

Altay, İ. F. (2008). A suggested syllabus for advanced writing skills at English language teaching departments (Unpublished doctoral dissertation). Hacettepe University, Institution of Social Sciences, Ankara, Turkey.

Arslan, A. (2012). Üniversite öğrencilerinin "topluluk karşısında konuşma” ile ilgili çeşitli görüşleri (Ağrı İbrahim Çeçen Üniversitesi örneği). Turkish Studies, 7(3), 221-231.

Bağcı, M. (2008). Öğretmenin beden dilinin ögrenciler tarafindan algılanması (Unpublished master's thesis). Beykent University, Social Sciences Institute, İstanbul, Turkey.

Baki, Y. \& Kahveci, G. (2017). Türkçe öğretmeni adaylarının konuşma kaygılarının etkili konuşma becerileri üzerindeki etkisi: Bir yapısal eşitlik modellemesi. Turkish Studies, 12(4), 47-70.

Baş, Ö. (2010). Öğretmenlerin sınıf içinde kullandiğı sözel ifadeler ve sözel olmayan davranışların analizi üzerine nitel bir araştırma (Unpublished doctoral dissertation). Gazi University, Institute of Educational Sciences, Ankara, Turkey.

Başaran, A. R. \& Baysal, S. (2016). Öğretmen adaylarının ideal bir öğretmen hakkındaki görüşleri. Ö. Demirel \& S. Dinçer (Eds.), Ĕgitim bilimlerinde yenilikler ve nitelik arayışı (pp. 29-43). Ankara: Pegem Akademi.

Başaran, M. \& Erdem, İ. (2009). Öğretmen adaylarının güzel konuşma becerisi ile ilgili görüşleri üzerine bir araştırma. Kastamonu Ĕgitim Dergisi, 17(3), 743-754.

Baykara Pehlivan, K. (2005). Öğretmen adaylarının iletişim becerisi algıları üzerine bir çalışma. Illkögretim Online, 4(2), 17-23.

Brooks, G. \& Wilson, J. (2015). Using oral presentations to improve students' English language skills. Kwansei Gakuin University Humanities Review, 19, 199-212.

Bryman, A. (2004). Triangulation. In M. S. Lewis-Beck, A. Bryman \& T. Futing Liao (Eds.), The SAGE Encyclopaedia of Social Science Research Methods (Vols. 1-3). Thousand Oaks, CA: SAGE Publications, Inc.

Büyüköztürk, Ş. (2006). Sosyal bilimler için veri analizi el kitabı. (6. Bask1). Ankara: Pegem A Yayıncilik.

Choudhury, R. U. (2014). The role of culture in teaching and learning of English as a foreign language. Express, an International Journal of Multi Disciplinary Research, 1(4), 1-20.

Council of Higher Education (2018). The undergraduate teacher education programs. Retrieved on the $2^{\text {nd }}$ of November, 2018 from https://www.yok.gov.tr/Documents/Kurumsal/egitim ogretim dairesi/Yeni-Ogretmen-YetistirmeLisans Programlari/AA_Sunus_\%20Onsoz_Uygulama_Yonergesi.pdf

Creswell, J. W. (2014). Research design: Qualitative, quantitative, and mixed methods approaches $\left(4^{\text {th }}\right.$ ed.). Thousand Oaks, CA, US: Sage Publications, Inc. 
Çalışkan, N. \& Yeşil, R. (2005). Eğitim öğretim sürecinde öğretmenin beden dili. Gazi Üniversitesi Kırşehir Eğitim Fakültesi Dergisi, 6(1), 199-207.

Çalışoğlu, M. (2019). Okul öncesi öğretmen adaylarının etkili sunum teknikleri üzerine görüşlerinin incelenmesi. Atatürk Üniversitesi Sosyal Bilimler Enstitüsü Dergisi, 23(1), 381-391.

Daly, C. \& Last, J. (2017). An analysis of free-choice electives in an undergraduate medical degree. BMC Medical Education, 17(1), 1-13.

Dilekmen, M., Başçı, Z., \& Bektaş, F. (2008). Eğitim fakültesi öğrencilerinin iletişim becerileri. Atatürk Üniversitesi Sosyal Bilimler Enstitüsü Dergisi, 12(2), 223- 231.

Doğan, Y. (2009). Konuşma becerisinin geliştirilmesine yönelik etkinlik önerileri. Türk Eğitim Bilimleri Dergisi, 7(1), 185-204.

Durukan, E. \& Maden, S. (2010). Türkçe öğretmenlerinin iletişim becerileri üzerine bir araştırma. Sosyal Bilimler Araştırmaları Dergisi, 1, 59-74.

Ekşi, G. (2008). A suggested syllabus for the ELT preparatory students at Gazi University in accordance with CEF B2 (vantage) level (Unpublished doctoral dissertation). Gazi University, Institute of Educational Sciences, Ankara, Turkey.

Eyüp, B. (2013). Üniversite öğrencilerinin konuşma becerilerini kullanmaya yönelik tutumları. Milli Ĕgitim Dergisi, 197, 95-113.

Göçer, A. (2013). Türkçe öğretmeni adaylarının dil kültür ilişkisi üzerine görüşleri: Fenomenolojik bir araştırma, Erzincan Üniversitesi Eğitim Fakültesi Dergisi, 15(2), 25-38.

Gündüz, N. (2005). A suggested syllabus for the course "Introduction to British Literature I" at ELT departments (Unpublished doctoral dissertation). Hacettepe University, Graduate School of Social Sciences, Ankara, Turkey.

Gürler, İ. (2018). Evaluation of the current curriculum in ELT departments from the perspectives of lecturers and students: A needs analysis (Unpublished doctoral dissertation). Atatürk University, Institute of Educational Sciences, Erzurum, Turkey.

Gürzap, C. (2011). Söz söyleme ve diksiyon (14. Bask1). İstanbul: Remzi Kitabevi.

Güvey Aktay, E. (2019). Sınıf öğretmeni adaylarının diksiyona ilişkin görüşleri. Eskişshir Osmangazi Üniversitesi Sosyal Bilimler Dergisi, 20, 431-449.

Hemmati, F. \& Mojarrad, H. (2016). E-learning and distance education: A study of Iranian teaching English as a foreign language master's students. Malaysian Journal of Distance Education, 18(1), 53-70.

Hennessy, E., Hernandez, M. R., Kieran, P., \& McLoughlin, H. (2010). Teaching and learning across disciplines: Student and staff experiences in a newly modularized system. Teaching in Higher Education, 15(6), 675-689.

Hoque, M. E. (2009). A language teacher: Qualities that a teacher must have. Teachers Qualities for the Present Age Conference, Bangladesh.

Howorth, C. A. (2001). An empirical examination of undergraduate students' module choices. International Journal of Management Education, 2(1), 19-30.

Ivankova, N. V., Creswell, J. W., \& Stick, S. L. (2006). Using mixed methods sequential explanatory design: From theory to practice. Field Methods, 18(1), 3-20. 
İşcan, A. \& Karagöz, B. (2016). Türkçe öğretmeni adaylarının konuşma kaygılarının incelenmesi (Gaziosmanpaşa Üniversitesi örneği). Ahi Evran Üniversitesi Kırşehir Eğitim Fakültesi Dergisi, 17(3), 193-206.

İşcan, A., Karagöz, B., \& Almalı, M. (2017). Öğretmen adaylarının sözlü anlatım dersine ve sözlü anlatıma yönelik tutumları üzerine bir çalışma. Uluslararası Türk Eğitim Bilimleri Dergisi, 5(8), 42-63.

Kahramanoğlu, R. \& Bay, E. (2016). Öğretmen yetiştiren kurumlar için giriş standartlarının belirlenmesi: Delphi çalışması. Eğitim ve Bilim, 41(187), 115-136.

Karakelle, S. (2005). Öğretmenlerin etkili öğretmen tanımlarının etkili öğretmenlik boyutlarına göre incelenmesi. Education and Science, 30(135), 1-10.

Katrancı, M. \& Kuşdemir, Y. (2015). Öğretmen adaylarının konuşma kaygılarının incelenmesi: Sözlü anlatım dersine yönelik bir uygulama. Dicle Üniversitesi Ziya Gökalp Eğitim Fakültesi Dergisi, 24, 415-445.

Kurkgöz, Y. (2007). English language teaching in Turkey: Policy changes and their implementations. RELC Journal, 38(2), 216-228.

Kızılaslan, İ. (2010). Yabancı dil öğretmen yetiştirme sürecinde kültürlerarasılık. Milli Eğitim Dergisi, 40(185), 81-89.

Köksal, D. \& Ulum, Ö. G. (2018). The state of EFL teacher education in Turkey: From past to present. ELT Research Journal, 7(4), 161-174.

Kuram, S. \& Çiftçi, E. (2018). Sınıf öğretmeni adaylarının ses eğitimi çalışmalarının konuşma becerilerine etkisi üzerine görüşleri. Sanat Eğitim Dergisi, 6(2), 113-129.

Majid, N. A., Jelas, Z. M., Azman, N., \& Rahman, S. (2010). Communication skills and work motivation amongst expert teachers. Social and Behavioral Sciences, 7, 565-567.

Meyer, D. Z. \& Avery, L. M. (2009). Excel as a qualitative data analysis tool. Field Methods, 21(1), 91-112.

Milli, M. S. \& Yağc1, U. (2017). Öğretmen adaylarının iletişim becerilerinin incelenmesi. Abant İzzet Baysal Üniversitesi Eğitim Fakültesi Dergisi, 17(1), 286-298.

Özkan, M. \& Arslantaş, H. ̇̇. (2013). Etkili öğretmen özellikleri üzerine sıralama yöntemiyle bir ölçekleme çalışması. Trakya Üniversitesi Sosyal Bilimler Dergisi, 15(1), 311-330.

Öztürk Yılmaztekin, E. (2015). İngilizce öğretmeni adaylarının etkili iletişim hakkındaki görüşleri. Mustafa Kemal Üniversitesi Sosyal Bilimler Enstitüsü Dergisi, 12(30), 63-77.

Palmer, T. A., Burke, P. F., \& Aubusson, P. (2017). Why school students choose and reject science: A study of the factors that students consider when selecting subjects. International Journal of Science Education, 39(6), 645-662.

Purcell, P., Dunnion, J., \& Loughran, H. (2010). Patterns of elective choice in the University College Dublin undergraduate curriculum. International Conference on Engaging Pedagogy, National University of Ireland Maynooth.

Sabir, R. I., Ahmad, W., Ashraf, R. U., \& Ahmad, N. (2013). Factors affecting university and course choice: A comparison of undergraduate engineering and business students in Central Punjab, Pakistan. Journal of Basic and Applied Scientific Research, 3(10), 298-305. 
Sadiku, L. M. (2015). The importance of four skills reading, speaking, writing, listening in a lesson hour. European Journal of Language and Literature Studies, 1(1), 29-31.

Samara, F. (2015) Factors influencing students' choice of elective science courses: A case study from the American University of Sharjah. Open Journal of Social Sciences, 3, 93-99.

Sanderson, D. (1983). Modern language teachers in action: A report on classroom practice. York: Language Materials Development Unit of the University of York.

Saraç, H. S. (2003). A suggested syllabus for the teaching of poetry course in ELT departments of Turkey (Unpublished master thesis). Hacettepe University, Institute of Social Sciences, Ankara, Turkey.

Selanik Ay, T. (2015). Etkili iletişim becerileri açısından eğitimciler. The Journal of Academic Social Science Studies, 41, 367-381. doi: http://dx.doi.org/10.9761/JASSS313

Stiles-Clarke, L. \& MacLeod, K. (2016). Choosing to major in physics, or not: Factors affecting undergraduate decision making. European Journal of Physics Education, 7(1), 1-12.

Şahin Baltacı, H. (2018). Okulda kişilerarası ilişkiler ve iletişim. A. Kaya (Ed.), İnsan İliş̧ileri ve İletişim (pp. 288-307). Ankara: Pegem Akademi.

Taşdemir, M., Taşdemir, F., Buyuran, N., \& Cesur, S. (2016). Öğretmenlerin insan ilişkileri hakkında aday öğretmen görüşleri. Eğitim ve Öğretim Araştırmaları Dergisi, 5(2), 196-207.

Taşkaya, S. M. (2012). Nitelikli bir öğretmende bulunması gereken özelliklerin öğretmen adaylarının görüşlerine göre incelenmesi. Mersin Üniversitesi Sosyal Bilimler Enstitüsü Dergisi, 33(2), 283298.

Temizkan, M. (2017). Evaluation of prospective teachers' oral presentation skills. Mustafa Kemal Üniversitesi Sosyal Bilimler Enstitüsü Dergisi, 14(39), 178-199.

Tezcan, H. \& Gümüş, Y. (2008). Üniversite öğrencilerinin seçmeli ders tercihlerine etki eden faktörlerin araştırılması. Gazi Eğitim Fakültesi Dergisi, 28(1), 1-17.

Thurmond, V. A. (2001). The point of triangulation. Journal of Nursing Scholarship, 33(3), 253-258.

Tran, T. Q. \& Pham, T. (2017). The importance of intercultural communicative competence in English language teaching and learning. Innovation and creativity in teaching and learning foreign languages Conference, HCMC Open University.

Ulusoy, Y.Ö., Dağ, F., Fidan, D., Sahranç, Ü., İnan, B., \& Güllü, D. (2012). Students' opinions about elective courses in changing education: The example of Kocaeli University Faculty of Education. Journal of Educational and Instructional Studies in the World, 2(4), 135-142.

Üstünsel, G. (2011). Etkili iletişim becerileri ve beden dili (Unublished master's thesis). Namık Kemal University, Institute of Natural and Applied Sciences, Tekirdağ, Turkey.

Yaman, İ. (2017). The role of culture in English language teaching. IX. Uluslararası Eğitim Araştırmaları Birliği Kongresi Eğitim Araştırmaları Birliği, Ordu.

Yanç, S. (2002). A suggested advanced reading course syllabus for the first year (first term) students in ELT departments (Unpublished master's thesis). Hacettepe University, Institute of Social Sciences, Ankara, Turkey.

Yang, X. (2017). The use of body language in English teaching. Theory and Practice in Language Studies, 7(12), 1333-1336. 
Yanpar Yelken, T., Çelikkaleli, Ö., \& Çapri, B. (2007). Eğitim fakültesi kalite standartlarının belirlenmesine yönelik öğretmen adayı görüşleri (Mersin Üniversitesi örneği). Mersin Üniversitesi Ĕ̈itim Fakültesi Dergisi, 3(2), 191-215.

Živković, S. (2014). The importance of oral presentations for university students. Mediterranean Journal of Social Sciences, 5(19), 468-475.

\section{Appendix A: English Language Teacher Education Curriculum (English Translation): 2018 Reform (CoHE, 2018)}

\begin{tabular}{|c|c|}
\hline \multicolumn{2}{|c|}{ COURSES- $1^{\text {ST }}$ YEAR } \\
\hline $\mathbf{1}^{\text {ST }}$ TERM & $2^{\mathrm{ND}}$ TERM \\
\hline Introduction to Education & Educational Psychology \\
\hline Educational Sociology & Educational Philosophy \\
\hline Atatürk's Principles and History of Revolution I & Atatürk's Principles and History of Revolution II \\
\hline Second Foreign Language I & Second Foreign Language II \\
\hline Turkish I & Turkish II \\
\hline Information Technology & Reading Skills II \\
\hline Reading Skills I & Writing Skills II \\
\hline Writing Skills I & Listening and Pronunciation II \\
\hline Listening and Pronunciation I & Oral Communication Skills II \\
\hline Oral Communication Skills I & Structure of English \\
\hline \multicolumn{2}{|c|}{$2^{\text {ND }}$ YEAR } \\
\hline $3^{\text {RD }}$ TERM & $4^{\text {TH }}$ TERM \\
\hline Instructional Technology & History of Turkish Education \\
\hline Teaching Principles and Methods & Research Methods \\
\hline Elective I (TPK) & Elective II (TPK) \\
\hline Elective I (GK) & Elective II (GK) \\
\hline Elective I (SAK) & Elective II (SAK) \\
\hline Approaches to ELT & English Language Teaching Programmes \\
\hline English Literature I & English Literature II \\
\hline Linguistics I & Linguistics II \\
\hline Critical Reading and Writing & Language Acquisition \\
\hline \multicolumn{2}{|c|}{$\mathbf{3}^{\mathrm{RD}}$ YEAR } \\
\hline $5^{\text {TH }}$ TERM & $6^{\text {TH }}$ TERM \\
\hline Classroom Management & Testing and Evaluation in Teaching \\
\hline Morals and Ethics in Education & Turkish Education and School Administration \\
\hline Elective III (TPK) & Elective IV (TPK) \\
\hline Elective III (GK) & Elective IV (GK) \\
\hline Elective III (SAK) & Elective IV (SAK) \\
\hline Teaching English to Young Learners I & Teaching English to Young Learners II \\
\hline Teaching Language Skills I & Teaching Language Skills II \\
\hline Literature and Language Teaching I & Literature and Language Teaching II \\
\hline \multicolumn{2}{|c|}{$4^{\text {TH }}$ YEAR } \\
\hline $7^{\text {TH }}$ TERM & $8^{\text {TH }}$ TERM \\
\hline Teaching Practice I & Teaching Practice II \\
\hline Special and Inclusive Education & School Counselling \\
\hline Elective V (TPK) & Elective V (TPK) \\
\hline Community Service Practices & Elective V (SAK) \\
\hline Elective V (SAK) & Testing in English Language Teaching \\
\hline
\end{tabular}




\begin{tabular}{|l|c|}
\hline School Experience & \\
\hline Translation & Total Credits: 155 \\
\hline & \\
\hline
\end{tabular}

\section{Appendix B: GK Elective Course Questionnaire}

Dear Participant,

In 2018, the Council of Higher Education made some regulations in English Language Teaching Programmes, and consequently students are required to take 4 "General Knowledge Electives" as part of their degrees. Considering the recent changes in ELT programmes, this questionnaire was designed to project a view on the preferences of pre-service and in-service EFL teachers.

Your sincere and volunteer contributions are of great importance for the reliability of the study. Your responses will be kept confidential and never associated with your name.

\section{Personal Information}

\section{Gender}

Female $\square \quad$ Male $\square$

Service Status

English Teacher / Lecturer

Pre-service English Teacher (Only English Language Teaching Students)

2. Please tick the major criterion for your preference of "General Knowledge Electives".

Lecturer

Course Title

Personal Needs and Interests

Contribution to Professional Development

Other

Please indicate:

3. Please choose 4 "General Knowledge Electives".

Understanding and Overcoming Addiction

Nutrition and Health

History and Philosophy of Science

Science and Research Ethics

Contemporary Turkish Literature

Diction

Economics and Entrepreneurship 
Presentation Skills

Traditional

Turkish

Handicrafts

First Aid

Democracy

and

Human

Rights

Human

Relations

and

Communication

Career Planning and Development

Language

and

Culture

Media

Literacy

Media and Communication

Professional English

Mythology

Music History

Art and Aesthetics

Cinema History

Sports

Traffic

Turkish Folk Dances

Turkish

Sign

Language

Turkish Cultural Geography

Traditional Turkish Music 
Turkish Art History

Other

Please indicate:

Thanks for your contribution.

\section{Appendix C: Diction Questionnaire}

Dear Lecturer,

I'm writing to you to get an opinion on how to design a syllabus for the elective course 'Diction'. In the first phase of my thesis study, the specified course was found the most preferred one by the participants. Therefore, in the second phase, I am in an endeavour to design a syllabus by collecting data from English language teacher educators working at Turkish universities. In this sense, I would like to invite you to complete the questionnaire below.

Could you please evaluate the following topics according to their importance in ELT (not important $=1$, slightly important $=2$, moderately important $=3$, important $=4$, very important $=5$ )

Thanks in advance for sharing your extensive knowledge and support.

\begin{tabular}{|c|c|c|c|c|c|c|}
\hline & & 1 & 2 & 3 & 4 & 5 \\
\hline 1 & Beden dili / Body Language & & & & & \\
\hline 2 & Boğumlama / Articulation & & & & & \\
\hline 3 & Diksiyonla İlgili Temel Bilgiler / Basics of Diction & & & & & \\
\hline 4 & Dil / Language & & & & & \\
\hline 5 & Diyafram çalışmaları / Diaphragmatic Breathing Exercises & & & & & \\
\hline 6 & Doğaçlama / Improvisation & & & & & \\
\hline 7 & Durak / Pause & & & & & \\
\hline 8 & Etkili Sunum Teknikleri / Presentation Skills & & & & & \\
\hline 9 & $\begin{array}{l}\text { Hazırlıklı ve Hazırlıksız Konuşmalar / Extemporaneous and } \\
\text { Impromptu Speeches }\end{array}$ & & & & & \\
\hline 10 & Hitabet / Oratory & & & & & \\
\hline 11 & İletişim Becerileri / Communication Skills & & & & & \\
\hline 12 & Jestler ve Mimikler / Gestures and Mimics & & & & & \\
\hline 13 & Konuşma Bozuklukları / Speech Disorders & & & & & \\
\hline 14 & Konuşma hızı / Rate of Speech & & & & & \\
\hline 15 & $\begin{array}{l}\text { Konuşma Terminolojisi ve Konuşma Türleri / Speech } \\
\text { Terminology and Types of Speech }\end{array}$ & & & & & \\
\hline 16 & Metin değerlendirme / Textual Analysis (Practice) & & & & & \\
\hline 17 & Nefes / Breathing training & & & & & \\
\hline 18 & Noktalama / Punctuation & & & & & \\
\hline 19 & Ses bilgisi (Fonetik) / Phonetics & & & & & \\
\hline 20 & Sözakımı / Fluency & & & & & \\
\hline 21 & Sözcük (kelime) / Vocabulary & & & & & \\
\hline 22 & Sözlü anlatım / Oral Narratives & & & & & \\
\hline 23 & Telaffuz / Pronunciation & & & & & \\
\hline
\end{tabular}




\begin{tabular}{|c|l|l|l|l|l|l|}
\hline $\mathbf{2 4}$ & $\begin{array}{l}\text { Topluluk Önünde Konuşma Denemeleri / Public Speaking } \\
\text { Practice }\end{array}$ & & & & & \\
\hline $\mathbf{2 5}$ & Ulama / Linking & & & & & \\
\hline $\mathbf{2 6}$ & Uygulama Çalış̧maları / Practice & & & & & \\
\hline $\mathbf{2 7}$ & Ünlüler ve ünsüzler / Vowels and consonants & & & & & \\
\hline $\mathbf{2 8}$ & Vurgu ve Tonlama / Stress and Intonation & & & & & \\
\hline
\end{tabular}

Other (Please specify)

\section{Appendix D: Suggested Syllabus for the Most Preferred Course: Diction}

\section{Weeks Topics}

1. Language

Basics of Diction

2. Voice and Breathing

3. Pronunciation

Phonetics

4. Articulation

Stress and Intonation

Fluency

5. Vocabulary

Body Language

Gestures and Mimics

6. Oral Narratives

7. Extemporaneous and Impromptu Speeches

Oratory

8. Communication Skills

9. Presentation Skills

10. Midterm

11. Public Speaking Practice

12. Public Speaking Practice

13. Practice

14. Practice 


\section{İngiliz dili eğitimi anabilim dalındaki genel kültür seçmeli dersleri hakkındaki görüşler: Diksiyon dersi için öğretim programı önerisi}

\section{$\ddot{O} \mathbf{z}$}

Yükseköğretim Kurulu (YÖK) seçmeli derslerin yüzdeliklerini artırarak, seçmeli derslerin sayıları, adları ve içeriklerindeki dağınıklıkları giderip, her bir alan için ortak seçmeli bir ders havuzu oluşturarak, öğretmen yetiştirme programlarının müfredatlarını güncellemiştir. Yapılan değişiklikler yeni seçmeli derslerin açılmasını gerekli hale getirdiği için, bu çalışmanın odak noktası olmuştur. Bu çalışmanın amacı İngilizce öğretmen adaylarının ve öğretmenlerinin en çok tercih ettiği 4 GK seçmeli dersini ve bu dersleri seçmelerini belirleyen kriterleri bulmak ve en çok tercih edilen GK seçmeli dersi için bir öğretim programı tasarlamaktır. İki aşamadan oluşan bu çalışmanın ilk aşamasında keşfedici sıralı karma yöntemden yararlanılmıştır. Araştırmacı tarafından 45 devlet üniversitesindeki İngiliz Dili Eğitimi bölümlerinin müfredatları incelenerek Genel Kültür seçmeli ders havuzlarındaki derslerin içerik analizi yapılmış ve bir anket geliştirilmiştir. Anket 1093 İngilizce öğretmen adayı ve öğretmenine çevrimiçi olarak uygulanmıştır. Nitel veri Microsoft Excel, nicel veri de SPSS 21.0 ile analiz edilmiştir. Çalışmanın ikinci aşamasında dönüştürücü karma yöntemden yararlanılmıştır. Araştırmacı tarafindan üniversitelerin farklı bölümlerinde yer alan Diksiyon dersi öğretim programları ve Diksiyon ile ilgili kaynak kitaplar incelenerek içerik analizi yapılmış ve bir anket geliştirilmiştir. Anket 114 İngilizce öğretmen eğitimcisine çevrimiçi olarak uygulanmıştır. Nitel veri Microsoft Excel, nicel veri de SPSS 21.0 ile analiz edilmiştir. İlk aşama kapsamında, İngilizce öğretmen adaylarının ve öğretmenlerinin en çok tercih ettiği 4 GK dersi 'Diksiyon', 'Etkili Sunum Becerileri', 'İnsan İlişkileri ve İletişim' ve 'Kültür ve Dil' olarak tespit edilmiştir. 'Kişisel ilgi ve gereksinimlere uygunluğu' katılımcılar tarafından GK seçmeli ders tercihlerini belirleyen en önemli kriter olarak belirtilmiştir. Çalışmanın ikinci aşamasında elde edilen sonuçlardan, Diksiyon dersine konu temelli öğretim programı önerisi için 18 konu belirlenmiştir. Çalışma sonucunda ortaya çıkan diğer bulgulara dayanarak çalışmanın sonunda öneriler sunulmuştur.

Anahtar sözcükler: İngilizce öğretmen adayları; İngilizce öğretmenleri; genel kültür seçmeli dersleri; öğretim programı önerisi; diksiyon

\section{AUTHOR BIODATA}

Ahu Akbay is an Instructor of English and has been working at the School of Foreign Languages at Canakkale Onsekiz Mart University since 2006.

Kürşat Cesur is a Dr. Lecturer at the ELT department of Canakkale Onsekiz Mart University, where he started working as an instructor of English in 2004. He has been working at the ELT Department of Faculty of Education since 2013. 